\title{
A REVIEW OF THE EFFECTS OF LAND-USE CHANGE ON SOCIAL SUSTAINABILITY IN AN EMERGING ECONOMY \\ Ogungbenro Matthew Taiwo ${ }^{*}$, Salfarina Samsudin², Dzurllkanian @ ZulkarnainDaud ${ }^{3}$, Olukolajo Michael Ayodele $^{4}$ \\ ${ }^{1,2,3}$ Faculty of Built Environment and Surveying Universiti Teknologi Malaysia (UTM), Malaysia, ${ }^{4}$ Federal University of Technology Akure (FUTA), Nigeria. \\ Email: ${ }^{1 *}$ mtogungbenro@graduate.utm.my, ${ }^{2}$ salfarina@utm.my, ${ }^{3}$ dzurll@utm.my, ${ }^{4}$ maolukolajo@futa.edu.ng
}

Article History: Received on $21^{\text {st }}$ August 2019, Revised on $29^{\text {th }}$ September 2019, Published on $06^{\text {th }}$ November 2019

\begin{abstract}
Purpose: The purpose of this study is to review the quest for physical development and economic viability which has overshadowed the social aspect of sustainable development that produces a liveable urban settlement in many emerging economies. Many of the urban areas of developing countries are characterized by sporadic/unguided land-use changes as a result of urbanization coupled with poor planning and management of land-use. Unfortunately, these changes are impacting negatively on the social fabric of sustainable and this calls for urgent attention.
\end{abstract}

Methodology: The study is based on an extensive review of literature on land-use changes and social sustainability in both the developed and emerging economies in order to identify gaps in practice and management of urban land development.

Main Findings: The results showed that although a considerable investment has been made and enormous efforts geared towards achieving sustainable development in Nigeria urban areas, little or no attention devoted to social sustainability in the planning and execution of these projects has rather led to unsustainable development. Many developmental projects and planning were politicized and thereby jettisoned social sustainability in the process.

Implication: It is important that urban land-use change should be appropriately monitored, purposively driven, and stakeholders must be responsive to promoting social sustainability to achieve a wholesome urban development.

Novelty: This study to the best of our knowledge is the first attempt that links urban land-use change and social sustainability especially in Nigeria. It has also provided information to guide the land-use planners, the policymakers and other stakeholders towards achieving a wholesome urban land-use development.

Keywords: Land-Use, Land-Use Change, Social Sustainability, Urbanisation, Sustainable Development.

\section{INTRODUCTION}

The quest to achieve a sustainable community cannot be overemphasized in any nation be it developed, developing, or emerging economies nation. Although many developing and emerging nations claim to imbibe sustainable development agenda, the reality on ground denies their commitment to the program (SDGs, Nigeria,2015). Most of the emerging economies countries are experiencing rapid growth of urbanization, that induced land-use change that has little or no concern for future generation (Musakwa \& Niekerk, 2013). The phenomenon is evident in haphazard development, overcrowding, and the collapse of infrastructure, urban pollution, and unguided mixed land-use that is capable of promoting crime.

Habitat, (2009) observed that many emerging economies of the world lack the capacity or requirement to manage their land-use and consequences of it are manifest on the social sustainability aspect of sustainable development. The pith of land-use planning is to deliver efficient physical development whose principal goal is to obtain a working, liveable environment that guarantees a common individual goal. However, it is appalling that land-use planning, in some cases, failed to incorporate social sustainability while pursuing sustainable development. Hicken, (2010) Noticed as well that spatial information to manage urban land-use in most of the African countries is either usually poor or not available. Ajibola and Ogungbemi (2011) Opined, be it individual, business, organization, community, reliable, accurate, and prompt information is essential in any decision making. Deficiency or inadequate information results in unwelcome or unfriendly decision or a situation wherein no decision will be taken. The dearth of reliable data is associated with most of our emerging economic countries. Tampering with the master plan, inadequate and unskilled human resources, causing a formidable obstacle to planning forecast and adequate monitoring of land-use are common features in Africa.

Land-use reflects the nature of economic activities and defines the structure of communities' development (Goetz, Shortle, \& Bergstrom, 2005). It is a reflection of human activities on the environment which if not effectively managed or monitored results in an unwelcome land-use change with a negatively impact on social sustainability. Whereas sustainable development connotes the use of land resources in a manner that prevents the elimination or reduction of their usefulness to the future generations; it is the right use of non- replaceable natural resources for the coming generation to continue benefiting from them. In order words, it is attaining the bearable level of attenuation of items of non- replaceable power resources to ensure sustenance of forthcoming consumers(Moldan, Janoušková, \& Hák, 2012). Unguided use of land in pursuit of physical developments often leads to changes in land-use at the expense of social sustainability. 
Unavailability of land space to accommodate the activities of the upsurge of the migrant population often give rise to the conversion of the uses such as agricultural land-uses to commercial, and most notably, the residential land-use into other types of land-uses. Thus communities that were predominantly residential settlements often change to mixed uses. This scenario has led to unguided development, jeopardizing sustainable development. Haphazard plan and rapid growth have contributed to the fast disappearance of urban green spaces and natural habitat (Abu Kasim, Yusof, \& Mohd Shafri, 2018). Where planning fails or too weak to checkmate haphazard land-use changes, the state often embarks on some corrective measures which on their own also qualify to be referred to changes in land-use. Examples of such measures can be compulsory acquisition and total clearance of properties to provide roads, open spaces, and other infrastructures to foster a liveable community. Therefore, it is against this backdrop that this paper studied the effect of land-use change on social sustainability in an emerging economy with a specific emphasis on Nigeria.

\section{LITERATURE REVIEW}

\section{Land-use Change-Nature and Causes}

Land-use change is a term used to describe the human's modification of the terrestrial surface of the earth. Humans have caused land-use changes on account of searching for food for the past thousands of years. However, the rate, dimension, and the intensity at which land-use change is occurring in recent times have become a global concern, most importantly as it drives unprecedented changes on ecosystems and environmental spheres. Omollo, Hayombe, and Owino, (2018) Observed that without adequate monitoring of urban land-use change, it would be difficult for any nation to attain its full economic development. Hassan et al., (2016) Observed that land-use change analysis is fundamental. Empirical studying by researchers from different disciplines revealed that land-use change had become a focal point to land-use related matters such as urban land-use agriculture, forestry, environment, and so forth.

Peter, Fateye, Oloke, \& Praise, (2018) Identified complete conversion of land-use from one type to another and the modification of particular use as the two forms of land-use changes. The former is concerned with changes in the mixed pattern of land-uses while the later involves changes in the intensity of use of a particular land majorly from underutilization to enhanced exploitation. The prevalent type of land-use change substantially documented in the body of literature is the change of agricultural and natural landscape to built-up areas (Braun, 2014;Balestrieri \& Ganciu, 2018). However, changes in land-use also occur, especially in urban settings when land or building change from the original use it was zoned and intended for (Tomisi, Oluwatosin, \& Samson, 2016). The driving forces behind this type of land-use change include forces of demand and supply, the complementarily of use, accessibility, planning regulations, development of infrastructural facilities, and an upsurge in population, rent, and circulation network to ease off traffic congestion. Others comprise; poor road network, housing short the age, pressure on existing infrastructural facilities, high crime rate, increase in rent and so forth (Gbadamosi and Ibrahim, 2013 in Tomisi et al., 2016). (Tomisi et al., 2016) posited that there is a need for government to regulate employing sound land-use policy, the urban land-use change/conversion to check the adverse effects that may result from it. However, (Department for International Development (DfID), 2015) warned that the check should be balanced so as not to become a $\operatorname{cog}$ in the wheel of urban physical and economic development.

Closely related terms to land-use change (LUC) are land-use cover change (LUCC) and land-use intensity change (LUIC). Whereas the former concerns a situation where a land parcel based on natural or human-made activities loses its original status; the latter is the opposite of land expansion, an alteration occasioned by compelling wants (Xiao, Qiu, \& Gao, 2016). Changes in the use of land will continue because of man's insatiable nature and quest to achieve optimal/highest and best use of land (Peter et al., 2018). The incessant desires to maximize economic returns on the part of the people and the need for local planning authorities to accommodate new spatial development/re-development necessitates some land-use changes especially in an urban setting (Peter et al., 2018). Whereas literature has established that unplanned and uncoordinated land-use can be characterized by negative externalities, government's induced land-use changes can be undertaken as a corrective measure to ameliorate its effect on the people and the environment.

\section{Concept of sustainable development}

Sustainable development is a worldwide accepted idea, even though some scholars tagged it as "a fuzzy concept" (Musakwa \& Niekerk, 2013). As summarised by Brunt land Commission, it is popularly referred to as "development that meets the present generation needs without compromising the fulfillment of the coming generation needs" (WCED, 1987). It is making a balanced decision today concerning land-use, environment, and socio-economic matters, without jeopardizing the future benefit of the coming generation (Abdullahi \& Pradhan, 2017). Sustainable development concept anchors on interdepended three pillars; these are ecological, economic, and social sustainability(OECD, 2016) refers to these components of sustainable development as an indivisible set of universal priorities.

\section{Ecological or environmental sustainability}

Abdullahi and Pradhan, (2017) Described environmental sustainability as utilization of renewable and non-renewable resources sustainably; avoiding the use of environmental resources as a sink of cities waste and pollution, and avoiding any act of disaster and practice that will incur adverse effects on natural environment and humans. Chiu, 2012 in Abdullahi \& Pradhan (2017) clarified that urban environmental problem is the outcome of urban sprawl, unguided development, and spatial segregation. Siong, (2007) Observed that $70 \%$ of overall carbon (CO2) emission is human-made due to land-use 
change and the rapid consumption of fossil fuel. Fossil fuel-based- power is one of the biggest challenges confronting our planet (Hennicke, 2005). (Siong, 2007) Posited that population and economic growth are the principal contributors to environmental problems.

Apart from the population growth and economic factors, (Fujita, Matsumoto, \& Siong, 2009) opined that building material used for construction emit $\mathrm{CO} 2$ in different quantities; timber houses emit lesser $\mathrm{CO} 2$ than reinforced cement- concrete building. Also, urban expansion does not only affect the urban dwellers and its environment; it extends its tentacle to rural settlement as well due to the rapid consumption of rural land cover or deforestation to meet the city forest material for building construction. The effect of this is more disastrous as it encourages desert encroachment. World ecology report, (2009) Warned on the devastating effect of desertification on the welfare and health of the inhabitant of the area witnessing land degradation and drought. The writer lamented that the Africa continent is suffering from this monster of the environment, as $46 \%$ of African landmass is under the degradation process and the reason is not unconnected with the inadequacy of land management. Therefore, forest resources sustainability must not be traded off with urban development vis-a-vis building material selection. Active monitoring of urban expansion and land-use change is more efficient in minimizing environmental effects. Ogujiuba, Ehigiamusoe, and Udefuna, (2015) Observed that sustainable development is a national challenge and is an unusual case in African society, Nigeria Urban cities are undergoing rapid urban expansion without regards to environmental consequences.

\section{Economic sustainability}

Economic sustainability entails making equitable and fiscally sound decisions without losing focus on other aspects of sustainability. Consequently, long term benefits of projects and decisions are paramount rather than just the short term benefit (Economic and Social Affairs, 2013). One of the problems confronting the developing countries concerning social and environmental challenges is their drive to have economic growth without adequate attention to its detrimental effects on social and ecological sustainability (Abdullahi \& Pradhan, 2017). The practice in developing nations is unlike the situation in developed economies where the concept of adjusting the economic model to obtain a balance between the social requirement and economic growth is the practice. Economic sustainability concerns with maintaining the natural, social, and human capital needed to achieve income and living standard (Vardon, Burnett, \& Dovers, 2016)

Although the three components of sustainable development are equally important, the picturesque view of sustainable development by (Krueger \& Buckingham, 2012)indicated the economic sustainability as the central focus enveloped by both social and environmental counterpart (see figure 1). (Xie, 2017)emphasized that more attention should be given to social and ecological sustainability to attain sustainable land-use and ensure human survival and that the economic benefit should not outweigh the social and environmental aspects of sustainability.

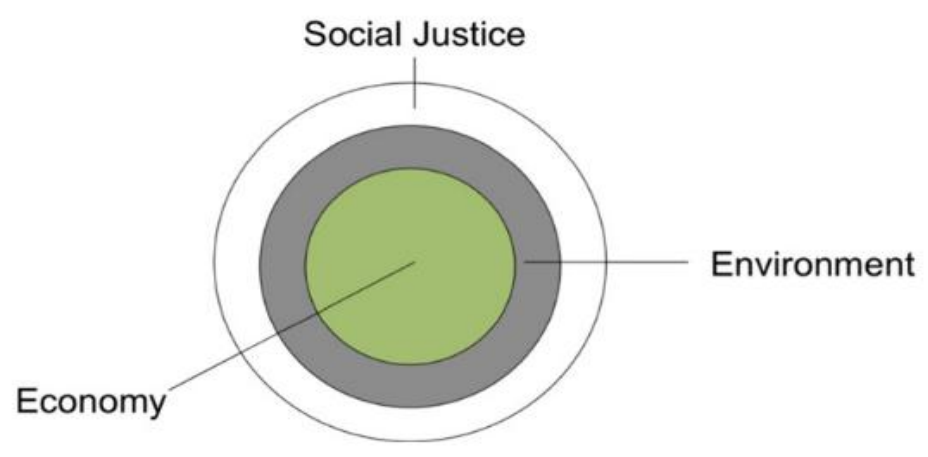

Figure 1: Urban sustainability formulation

Source: Kruenger and Buckingham (2012)

\section{Social sustainability}

Social sustainability is most connected to human needs than the other two counterparts of sustainable development. If human problems are to be solved sustainably, suggested that the primary focus should be the people while considering various available alternatives in resolving the issue. Thus, it is imperative to integrate people's opinions in the process. Yung and Chan, (2016) Described social sustainability with a focus on cities' environment as a compatible development that is harmonious with the vibrant civic society; raising an environment that supports cohabitation of socially and culturally diverse persons and at the same time boosting social integration, together with advancements in the better state of life to all sectors of the population. It is the ability of a city to continuing functioning as the right place for human relations, cultural development, and communication. Development is considered socially sustainable, if it enhanced a harmonious living society, minimizes social inequality and cleavages, and promotes a general quality of life (Chan \& Lee, 2008).

Indicators for measuring social sustainability, as compiled from a literature search by Dempsey and Bramley, (2009) were categorized into non- physical and predominantly physical factors (see Table 1). 
Table 1: Urban social sustainability: contributory factors as identified in the review of literature

\begin{tabular}{|c|c|}
\hline Non-physical factors & Predominantly physical factors \\
\hline - Education and training & - Urbanity \\
\hline - Social justice: and inter and intra- & - Attractive public realm \\
\hline - Participation and local democracy & - Decent housing \\
\hline - Health, quality of life and well-being & - Local environmental quality and amenity \\
\hline $\begin{array}{l}\text { - Social inclusion (and eradication of social } \\
\text { exclusion) }\end{array}$ & $\begin{array}{lllll}\text { - Accessibility (e.g. to local services and } \\
\text { facilities/employment/green space) }\end{array}$ \\
\hline - Social capital & - Sustainable urban design \\
\hline - Community & - Neighbourhood \\
\hline - Safety & - Walkable neighbourhood: pedestrian friendly \\
\hline - Mixed tenure & \\
\hline - Fair distribution of income & \\
\hline - Social order & \\
\hline - Social cohesion & \\
\hline $\begin{array}{l}\text { - Community cohesion (i.e. cohesion } \\
\text { between and among different groups) }\end{array}$ & \\
\hline - Social networks & \\
\hline - Social interaction & \\
\hline - Sense of community and belonging & \\
\hline - Employment & \\
\hline - Residential stability (vs turnover) & \\
\hline - Active community organizations & \\
\hline - Cultural traditions & \\
\hline
\end{tabular}

Source:Dempsey and Bramley, (2009)

Rashidfarokhi, Yrjänä, Wallenius, Toivonen, Ekroos, and Viitanen (2018) compiled through literature search the relevant social sustainability elements that can be used to assess land-use planning process. As many as 120 elements were first identified in the first stage of selection. This was trimmed down to 45 at the end of the second stage after eliminating similar content. At the third stage, irrelevant elements were removed, leaving 26 factors that were finally categorised to 6 general themes at the last stage. The essence of this was to limit the scope to a manageable number to facilitate economic and physical monitoring and assessment of a process feasible towing the path of (Pearce \& Venegas, 2002). The six final themes are (1) equity, (2) social inclusion, (3) social cohesion, (4) social capital, (5) community participation, and (6) safety. Table 2 shows each of these themes and their elements.

Table 2: Six general themes and the related social sustainability elements

\begin{tabular}{ll}
\hline General Theme & Social Sustainability Elements \\
\hline 1) Equity & $\begin{array}{l}\text { Equal opportunities and access to resources; Inter and intra-generational equity; Gender } \\
\text { equity; Equity for minorities and disadvantaged groups }\end{array}$ \\
\hline 2) Social inclusion & Diversity; Arts and culture; social integration; social mixing; conflicts mitigation \\
\hline 3) Social cohesion & $\begin{array}{l}\text { Community vitality; Active community organizations; Accessibility to institutions; } \\
\text { Innovation and process; Citizen perception of government performance; Social solidarity; } \\
\text { Civic engagement and volunteerism }\end{array}$ \\
\hline 4) Social capital & $\begin{array}{l}\text { Social norms; Social values; Social / civic networks; Trust and optimism; Access to civic and } \\
\text { public spaces }\end{array}$ \\
\hline $\begin{array}{l}\text { 5) Community } \\
\text { participation }\end{array}$ & Knowledge management; Community empowerment; Partnership and collaboration \\
\hline 6) safety & Security; Freedom, Resilience \\
\hline
\end{tabular}

Source: Rashidfarokhi, Yrjänä, Wallenius, Toivonen, Ekroos\&Viitanen (2018)

\section{Equity}

A socially sustainable community provides equal access to resources and opportunities to all irrespective of their gender differences (Bidram \& Davoudi, 2012; Dempsey et al., 2011). Equity covers the well-being of minorities and disadvantaged groups across geographical spheres, inter, and itra-generational equity (Ancell \& Thompson-Fawcett, 2008; Eames \& Adebowale, 2002). With this, social justice is achieved and prepares people to fully and actively participate in matters that concern them and the public at large (DESA, 2009). 


\section{Social Inclusion}

Through social inclusion, there is a feeling of belonging among people. Social sustainability is actualized, when people with different backgrounds feel respected, understood, fairly represented, and socially mixed (Darchen \& Ladouceur, 2013; Colantonio \& Dixon, 2010). In this way, people's knowledge and concerns are catered for right from the planning stage (De Lange \& De Waal, 2013). Social inclusion ensures that all individuals in society do participate, respected, valued, and make a contribution to issues that concern them based on five principles which are human development, valued recognition, proximity, involvement and engagement, and material well-being (Donnelly \& Coakley, 2002).

\section{Social Cohesion}

This 1 refers to the extent and nature of the interaction between and within those involved in the planning process (Forrest \& Kearns, 2001; Holman \& Rydin, 2013). Social cohesion is described as the cohabitation of groups which are socially and culturally diverse. By this, the diverse group in the society are integrated by social activities, thus preventing social exclusion.

\section{Social Capital}

Putnam, (2000) Described social capital as 'social networks and the associated norms of reciprocity.' It is fostering relations that result in product benefits among the people, and also refers to features of the social organization including trust, the density, and knowledge of relationships within networks and obligations and expectations (Pennington \& Rydin, 2000).

\section{Community Participation}

Through community participation, people are allowed to influence decision-making processes. Akinmoladun \& Oduwaye, (2000) Posited that local people feel belonging when they are incorporated into the decision-making process. Through this specific need of the people are met.

\section{Safety}

Safety is about the right of the individual to protection and security in a situation of vulnerability. Land-use change or development must be able to address the safety of community health, their quality of life, and wellbeing and guarantee their decent housing.

Eizenberg and Jabareen, (2017) Explained that where there are equity and justice, there will be less inequality and greater justice that minimized the alienation of residence from their place of living and thus heighten their concern to environmental matters. The community must permit the participation of people in local democracy, encourage training and education; promote the residents' economy, allows social inclusion, cohesion, interaction, social network, social capital, employment, and mixed tenure. Social sustainability in an urban context was conceptualized and defined based on the literature search (see table 3). Although this classification is similar to (Rashidfarokhi et al., 2018) their view specifies the expectation of people with any developmental project and planning in an urban area. Unfortunately, the human-induced land-use change most times cannot guarantee the availability of these attributes of social sustainability. In situations where people embark on uncoordinated use and change of use of urban land without recourse to the state regulation, it is doubtful if the result of their action can deliver expected satisfaction beyond immediate times such activities are undertaken. Greed and desire for financial gain are often responsible for the unauthorized use of land among the people. On the part of the government, politicizing development process, among others is a detriment to good governance; this contributes to unsustainable land-use. A desirable sustainable development takes cognizance of all the pillars, as mentioned earlier, which are, environment, economic, and social sustainability.

Table 3: General aspects in reviewing social sustainability in relation to the urban context

\begin{tabular}{ll}
\hline General Theme & Definition/meaning \\
\hline Social Equity & $\begin{array}{l}\text { Includes equity of access to key services (including health, education, transport, housing, } \\
\text { and recreation) highlighted in almost every reference }\end{array}$
\end{tabular}

\begin{tabular}{|c|c|}
\hline $\begin{array}{l}\text { Satisfaction or Human } \\
\text { needs }\end{array}$ & $\begin{array}{l}\text { Relevant to individuals, it follows Maslow's hierarchy of needs and covers physiological } \\
\text { (food, water, health, and safety), social (relationships, confidence, and mutual respect) } \\
\text { and self-actualization (creativity and morality) levels (Ahman, 2013; Ancell \&Thompson- } \\
\text { Fawcett, 2008) }\end{array}$ \\
\hline Well-being, Happiness & $\begin{array}{l}\text { This includes the individual political and civic liberties, access to both the physical and the } \\
\text { materials necessities of human society (Overton, 1996) }\end{array}$ \\
\hline Quality of Life & $\begin{array}{l}\text { It is the sum or factors that contribute to the social, environmental and economic wellbeing } \\
\text { of citizens. It covers aspects such as well-being, happiness, and satisfaction. } \\
\text { (Weingaetner \& Moberg, 2011; Polesec \& Stren, 2000; McKenzie, 2004; Colantino, 2010) }\end{array}$ \\
\hline
\end{tabular}




\begin{tabular}{|c|c|}
\hline $\begin{array}{lr}\text { Social } & \text { Interaction, } \\
\text { Social } & \text { Mixing } \\
\text { (Cohesion } & \text { and } \\
\text { Inclusion) } & \end{array}$ & $\begin{array}{l}\text { It is about the right and opportunities to participate in community and interact with other } \\
\text { members of community. It encompasses cohabitation of culturally and socially diverse } \\
\text { groups in societies where people Involve in a wide variety of social activities and } \\
\text { preventing social exclusion. } \\
\text { (Ancell \& Thompson-Fawcett, 2008; Bramley, Dempsey, Power, Brown, \& Watkins, } \\
\text { 2009; Dempsey, Brown, \& Bramely, 2012; Bacon, Cochrane, \& Woodcraft, 2012; } \\
\text { Sedaghatnia et al., 2015; Mehan, 2016) }\end{array}$ \\
\hline $\begin{array}{l}\text { Pride, sense of Place } \\
\text { and culture (Identity) }\end{array}$ & $\begin{array}{l}\text { It is about people's precipitations of a particular place. It mainly relates to a definite sense } \\
\text { of attachment, dependent and identity that people feel about the place they live. } \\
\text { (Dempsey, Bramley, Power, \& Brown,2011) }\end{array}$ \\
\hline Sense of Comr & $\begin{array}{l}\text { It is about the social interaction of people living in a given area, related to a sense of } \\
\text { community or place attachment. } \\
\text { (Dempsey, Bramely, Power, \& Brown, 2011; Barron \&Gaunllett, 2002; Castillo, Price, } \\
\text { Moobela., \&Mathur, 2007; Bramley, Dempsey, Power, Brown, \&Vaikins, 2009; Colantino, } \\
\text { 2010; Landorf, 2011; Bacon, Cochrane, \& Woodcraft, 2012) }\end{array}$ \\
\hline Futur & $\begin{array}{l}\text { Social sustainability is primarily about valuing and protecting positive aspects of cultures. } \\
\text { (McKenzie, 2004; Magis \& Shinn, 2009; Ghahramanpouri et al, 2015) }\end{array}$ \\
\hline
\end{tabular}

Source: Adopted and modified from (Mehan \& Farzaneh, 2017).

\section{SUSTAINABLE URBAN LAND-USE CHANGE}

Urban areas are characterized by changes in the use of land over time. The change is dynamic and sometimes unavoidable, but must be controlled. Unfortunately, In developing countries, there exists a lack of required data needed in monitoring sustainable land-use(Musakwa \& Niekerk, 2013). Unsustainable land-uses may do more harm than good. Zheng, Shen, Wang, and Hong, (2015) Noted that monitoring land-use change is very important for policy and decision making. Analyzing land-use change, and its driving force is vital when sustainable land-use is contemplated. While analysing landuse change in $\mathrm{Li}$ and Liu, (2017) observed an increase in built-up area to the detriment of rural farmland cultivation, loss of urban land due to irrational urban planning and inability of land-use policy to protect the rural land-use from gross encroachment of urban land-use. This is very common in many developing countries.

A comprehensive evaluation of the sustainability of urban land-use is a necessity; it provides land-use information that planners can work with. Izakovi \& Špulerov, (2018) Opined that before sustainable land-use management can be achieved, there is a need first to determine and negate the causality and drivers of land-use changes. A series of models have been propounded to understand and assist land-use changes as the basis for planning and sustainable management. Land-use change models are used as tools in analyzing the causes and consequences of land-use change (Verburg, etal., 2004).

\section{LAND-USE AND SOCIAL SUSTAINABILITY IN NIGERIA}

There generally exists a dearth of literature on social sustainability in respect of land-use in Nigeria because this aspect of sustainable development has not sufficiently drawn the attention of the policymakers and other stakeholders. Ogujiuba $\mathrm{et}$ al., (2015) Noted that many cities in Nigeria are vulnerable to flooding, natural disaster, and poor people live in unsafe housing and the environment. Tunmise, Ayodele and Abimbola, (2015) Compared the development and living condition of people in Makoko, Lagos, and Empire Square, London. It was concluded that the situation at Makoko Lagos was a total disregard for social sustainability, unlike the situation at the Empire Square, London. Social sustainability was not achieved in the Makoko area of Lagos State as the government could not provide affordable housing, access to social amenities, and infrastructure among people. Tunmise et al. (2015) Noted that there is conflicting interest towards social sustainability while creating cities; government policy and action on slum clearance has an element of inequality and social injustice on the social wellbeing of people. (Raheem and Adeboyejo, 2016) Reported that urban green space, including private open space cover with vegetation that accommodates park, garden, wetland, urban tree, children play, outdoor recreational, place of relaxation are fast eroding from our urban cities due to rapid urbanization and poor or low interest in green space. Ibadan city has suffered from natural cover depletion due to land-use change as a result of its uncontrolled development (Enisan\& Aluko, 2015; Arimah and Adeagbo, 2000) noted that non-implementation of land-use policies is attributed to the weak administrative system of land-use policy.

Ogbazi, (2013) Reviewed the progress of sustainable cities program in Nigeria concerning Ibadan in the South West, Enugu in the East and Kano in Northern Nigeria using 21 variables. It was noted that progress was not made in 9 items out of these variables especially in providing adequate information, engaging the media, building strong government support, completing demonstration projects, use of law and regulations, and city consultations. These aspects, especially the provision of adequate information, could mar the whole exercise. The information available to the people will determine social inclusion, cohesion, and ultimately participation. These are all pointers to social sustainability.

In a study on Ibadan city, Raheem and Adeboyejo (2016) reported that the city had undergone upsurge of the population with territorial expansion without any recognition for the attenuation of a greenish environment. The development has 
resulted in unsustainable social development that is evident in annual flooding, air, and land pollution, loss of aesthetic, among others. Akanle \& Adejare, (2015) emphasized a phenomenon whereby nobody care to build according to specification or to obey the urban planning rule and regulation likely result in the annual or perennial flooding that the city of Ibadan is experiencing. Lack of adherence to social sustainability in the development agenda of the town has tag the town as one of the unsustainable social cities.

The study of Oduwaye, (2013) on hanging land-use structure of metropolitan Lagos, Nigeria revealed that one of the factors that drove land-use changes was the rapid loss of industrial land-use to alternative uses of which religious uses were significant. The religious organizations were the only potential users who could pay the demanded rents on the premises. The study also noted that the governments were the accomplice of undesirable land-use changes. This is due to approving uncomplimentary land-uses by government agencies in a bid to improve the state's revenue through taxes, levies, and other financial returns. All these are a pure disregard for social sustainability in favor of physical development and economic gain.

Bagaeen \& Uduku, (2010) Describes another dimension of urban social unsustainable practice in the development of gated communities instead of beefing up the security of urban communities. They argued that this does not encourage social interaction and integration between different social groups living inside and outside the walls of these protected residential settlements.

The nature and causes of land-use change around Ekiti State University in Ado Ekiti, Nigeria, was studied by Owoeye, 2015. The study revealed that the main driver of land-use change around the university was the financial return from the use of land. Lands that were developed to provide accommodation to students and university workers were found to yield higher financial returns far above those used for agricultural purposes. Consequently, haphazard development sprang up without regard for planning approval and sustainability need for development. The consequence of this development is environmental degradation and congestion, which are capable of hindering the social sustainability of the community. It is noted from this study; among others that weak planning authority is a significant factor that contributes to landowners' use of their land with little or no restriction.

\section{CONCLUSION}

A considerable investment has been made and enormous efforts geared toward achieving sustainable development in Nigeria. However, until the developmental efforts take cognizance of all the three constituents of sustainable development, that is, environmental, economic and social sustainability, the situation will remain like a bird flying with one wing, or a tripod having a bad leg. Of all these aspects, it is noticeable that not much has been achieved in social sustainability. The reason for this is not far-fetched. Many developmental projects and planning were politicized and thereby jettisoned social sustainability in the process. The (UNDP, 2016) identifies measures and characteristics of good governance in respect to urban issues:

1. Participation - all the stakeholders, should have a voice in decision-making either directly or through legitimate intermediate institutions that represent their interest. Participation is achievable through freedom of speech and association, as well as capacities to participate constructively

2. Rule of law - impartiality and fairness in the enforcement of legal frameworks, particularly the laws that establish human rights.

3. Transparency - information should flow freely. People should not be in the dark towards government activities. This will aid in the effective monitoring of the processes.

4. Responsiveness - every stakeholder must be served without discrimination.

5. Consensus orientation -it is expected of good governance to mediate between different groups to reach a consensus that will be beneficial to all in respect of policies and procedures.

6. Equity - equal opportunities to all for maintenance and improvement of their wellbeing irrespective of their gender differences.

7. Effectiveness and efficiency - propagating a process and institutions that are result oriented to meet needs within a justifiable use of available resources.

8. Accountability decision - being subject to the public, the makers in government, the civil society, and private organizations are made accountable to the public.

9. Strategic vision - this refers to having a good foresight on human development and good governance, geared towards what is needed in actualizing the needed development. This has nexus with an understanding of the history, culture, and social complexities.

Also, the word of (Simon, 2015) our common future should be strictly adhered to if social sustainability should be achieved, governments should embark on an unequivocal settlements policy to regulate the urbanization process, the 
strategies should be directed at elevating the urbanization pressure off the big urban centres. Also, human beings should be the focus of any land-use development at both private and public levels to achieve social sustainability.

All these highlighted points are only possible where social sustainability is in the right focus. Monitoring urban land-use is the responsibility of a good government. A reckless and unguided urban land-use change will jeopardize the interest of the coming generations and where the stakeholders turn deaf ears, more harm will be done than good. Arising from the preceding, it is recommended that urban land-use change should be appropriately monitored, purposively driven, and stakeholders must be responsive to promoting social sustainability to achieve a wholesome urban development.

\section{REFERENCE}

1. Abdullahi, S., \& Pradhan, B. (2017). Sustainable Urban Development. https://doi.org/10.1007/978-3-319-54217-1

2. Abu Kasim, J. B., Yusof, M. J. M., \& Mohd Shafri, H. Z. (2018). Urban Green Space Degradation: An Experience of Kuala Lumpur City. Environmental Management and Sustainable Development, 8(1), 27. https://doi.org/10.5296/emsd.v8i1.13917

3. Ahman, H. (2013). Social Sustainability-Society at the intersectionof development and maintanance. (, Ed.) Local Environment, 18 (10),1153-1166. https://doi.org/10.1080/13549839.2013.788480

4. Ajibola M. O. and Ogungbemi A. O. (2011). Importance of Accessibility to Reliable Data for Real Estate Practice, 2(2), 223-231.

5. Akanle, O., \& Adejare, G. (2015). Ethnography of Flooding in Ibadan Metropolis, Nigeria: Agencies of Flooding in Developing Countries, (May 2018).

6. Akinmoladun, I. O., \& Oduwaye, L. (2000). Democratizing the Planning Process in Nigeria through Public Participation: A Challenge to Town Planners in the Twenty-First Century. Journal of the Nigerian Institute of Town Planner, 13(2), 1-11.

7. Ancell, S., \& Thompson-Fawcett, M. (2008). The social sustainability of medium density housing: A conceptual model and Christchurch case study. Housing Studies, 23(3), $423-442$. https://doi.org/10.1080/02673030802029990

8. Arimah, B. C., \& Adeagbo, D. (2000). Compliance with urban development and planning regulations in Ibadan, Nigeria. Habitat International, 24(3), 279-294. https://doi.org/10.1016/S0197-3975(99)00043-0

9. Bacon, N., Cochrane, D., \& Woodcraft, S. (2012). Creatingstrong communities: How to measure the socialsustainability of new housing developments: Developingthe framework. The berkley Group. London: The BerkleyGroup.

10. Bagaeen, S., \& Uduku, O. (2010). ated communities: social sustainability in contemporary and historical gated developments. Routledge.

11. Balestrieri, M., \& Ganciu, A. (2018). Landscape changes in rural areas: A focus on sardinian territory. Sustainability (Switzerland), 10(1), 1-16. https://doi.org/10.3390/su10010123

12. Barron, L., \& Gauntlett, E. (2002). Housing and SustainableCommunities Indicators Project: Stage 1 ReportModel of social sustainability. WACOSS(Western Australia Councilof Social Service).

13. Bidram, A., \& Davoudi, A. (2012). Hierarchical structure of microgrids control system. IEEE Transactions on Smart Grid, 3(4), 1963-1976. https://doi.org/10.1109/TSG.2012.2197425

14. Bramley, G., Dampsey, N., Power, S., Brown, C., \&Watkins,D. (2009). Social Sustainability and urban form: evidencefrom five British cities. (Ed.) Environment and Planning, 41 (9). https://doi.org/10.1068/a4184

15. Braun, J. Von. (2014). Nature and Agriculture - the Evolving Relationships, (October), 1-9.

16. Castillo, H., Price, A., Moobela, C., \& Mathur, V.(2007). Assessing urban social sustainability: currentcapebilities and ippurtunities for future reseach.The InternationalJournal of Environmental, Cultural, Economicand Social Sustainability, 3 (3), 39-48. https://doi.org/10.18848/1832-2077/CGP/v03i03/54355

17. Chan, E., \& Lee, G. K. L. (2008). Critical factors for improving social sustainability of urban renewal projects. Social Indicators Research, 85(2), 243-256. https://doi.org/10.1007/s11205-007-9089-3

18. Colantino, A. (2010). Urban Social sustainability thems andassessment methods. Proceeding of the institution ofcivil engineers: Urban Design and planning, 163 (2),79-88. https://doi.org/10.1680/udap.2010.163.2.79

19. Colantonio, A., \& Dixon, T. (2010). Social sustainability and sustainable communities: Towards a conceptual framework. Urban Regeneration \& Social Sustainability: Best Practice from European Cities, 18-36. https://doi.org/10.1002/9781444329445.ch2

20. Darchen, S., \& Ladouceur, E. (2013). Social sustainability in urban regeneration practice: a case study of the Fortitude Valley Renewal Plan in Brisbane. Australian Planner, 50(4), $340-350$. https://doi.org/10.1080/07293682.2013.764909

21. De Lange, M., \& De Waal, M. (2013). Owning the city: New media and citizen engagement in urban design. First Monday, 18(11). https://doi.org/10.5210/fm.v18i11.4954

22. Dempsey, N., \& Bramley, G. (2009). The Social Dimension of Sustainable Development:, (April 2018). https://doi.org/10.1002/sd.417

23. Dempsey, N., Bramley, G., Power, S., \& Brown, C. (2011). The Social Dimension of Sustainable Development: Defi ning Urban Social Sustainability. Sustainable Development, 19(May 2009), $289-300$. https://doi.org/10.1002/sd.417 
24. Department for International Development (DfID). (2015). Urban infrastructure in Sub - Saharan Africa harnessing land values, housing and transport, (May), 1-47.

25. DESA, D. (2009). Creating an inclusive society: practical strategies to promote social integrationHabimana, P \& Kaze, E. Division for Social Policy and Development United Nations Department of Economic and Social Affairs.

26. Donnelly, P., \& Coakley, J. (2002). PERSPECTIVES ON SOCIAL INCLUSION The Role of Recreation in Promoting Social Inclusion.

27. Eames, M., \& Adebowale, M. (2002). Sustainable development and social inclusion: Towards and integrated approach to research.

28. Economic and Social Affairs. (2013). World Economic and Social Survey 2013: Sustainable Development Challenges. United Nations, Department for Economic and Social Affairs. https://doi.org/10.1016/j.urolonc.2009.06.002

29. Eizenberg, E., \& Jabareen, Y. (2017). Social Sustainability: A New Conceptual Framework. Sustainability, 9(1), 68. https://doi.org/10.3390/su9010068

30. Enisan, G., \& Aluko, E. (2015). Process of Urban Land-use in Nigeria, 3(8), 87-100.

31. FAO/UN-HABITAT, 2009. (2009). Planning Sustainable Cities.

32. Forrest, R., \& Kearns, A. (2001). Social cohesion, social capital and the neighbourhood. Urban Studies, 38(12), 2125-2143. https://doi.org/10.1080/00420980120087081

33. Fujita, Y., Matsumoto, H., \& Siong, H. C. (2009). Assessment of CO2emissions and resource sustainability for housing construction in Malaysia. International Journal of Low-Carbon Technologies, 4(1), 16-26. https://doi.org/10.1093/ijlct/ctp002

34. Ghahramanpouri, A., Saifuddin Abdullah, A., Sedaghatnia,S., \& Lamit, H. (2015). Urban Social SustainabilityContributing Factors inKuala Lampur Streets. Asian Conferenceon Environment-Behaviour Studies 368-376. https://doi.org/10.1016/j.sbspro.2015.08.188

35. Goetz, S. J., Shortle, J. S., \& Bergstrom, J. C. (2005). Land-use Problems and Conflicts.

36. Habitat, U. N. (2009). The right to adequate housing., No, 21.

37. Hassan, Z., Shabbir, R., Ahmad, S. S., Malik, A. H., Aziz, N., Butt, A., \& Erum, S. (2016). Dynamics of land-use and land cover change (LULCC) using geospatial techniques: a case study of Islamabad Pakistan. SpringerPlus, 5(1). https://doi.org/10.1186/s40064-016-2414-Z

38. Hennicke, P. (2005). Long term scenarios and options for sustainable energy systems and for climate protection: A short overview. International Journal of Environmental Science and Technology, 2(2), 181-191. https://doi.org/10.1007/BF03325874

39. Hicken, E. (2010). Application of GIS at local government level. GIS Technical, (June), 39-45.

40. Holman, N., \& Rydin, Y. (2013). What Can Social Capital Tell Us About Planning Under Localism? Local Government Studies, 39(1), 71-88. https://doi.org/10.1080/03003930.2012.675330

41. Izakovǐ, Z., \& Špulerov, J. (2018). Integrated Approach to Sustainable Land-use Management. https://doi.org/10.3390/environments5030037

42. Krueger, R., \& Buckingham, S. (2012). Towards a "Consensual" Urban Politics? Creative Planning, Urban Sustainability and Regional Development. International Journal of Urban and Regional Research, 36(3), 486503. https://doi.org/10.1111/j.1468-2427.2011.01073.x

43. Landorf, C. (2011). Evaluating social sustainability inhistoric urban environments. International Journal ofHeritage Studies, 17 (5), 463-477. https://doi.org/10.1080/13527258.2011.563788

44. Li, Y., \& Liu, G. (2017). Characterizing spatiotemporal pattern of land-use change and its driving force based on GIS and landscape analysis Techniques in Tianjin during 2000-2015. Sustainability (Switzerland), 9(6). https://doi.org/10.3390/su9060894

45. McKenzie, S. (2004). Social Sustainability: Towards somedefinitions. Hawke Research Institute. Magill, SouthAustralia: University of South Australia.

46. Mehan, Asma. 2016. "Public Squares and Their Potentialfor Social Interactions:A Case Study of Historical PublicSquares in Tehran." International Journal of Architecturaland Environmental Engineering (World Academyof Science, Engineering and Technology) 3, no. 2: 547.

47. Mehan, A., \& Farzaneh, S. (2017). Social sustainability in urban context: Concepts, definitions , and principles, (February). https://doi.org/10.1201/9781315226255-47

48. Moldan, B., Janoušková, S., \& Hák, T. (2012). How to understand and measure environmental sustainability: Indicators and targets. Ecological Indicators, 17, 4-13. https://doi.org/10.1016/j.ecolind.2011.04.033

49. Musakwa, W., \& Niekerk, A. Van. (2013). Implications of land-use change for the sustainability of urban areas: A case study of Stellenbosch, South Africa. Cities, 32, 143-156. https://doi.org/10.1016/j.cities.2013.01.004

50. Oduwaye, L. (2013). $\square$ reviewed paper Urban Planning Implications of Changing Land-use Structure of Metropolitan Lagos, Nigeria Leke Oduwaye, 4(May), 20-23.

51. OECD. (2016). FDI in figures. Oecd, (April), 1-8.

52. Ogbazi, J. U. (2013). Alternative planning approaches and the sustainable cities programme in Nigeria. Habitat International, 40, 109-118. https://doi.org/10.1016/j.habitatint.2013.03.001

53. OgujiubaK., Ehigiamusoe U. K., \& Udefuna, P. (2015). The Challenges and Implications of Sustainable Development in Africa: Policy Options for Nigeria, Ogujiuba Kanayo 1, Ehigiamusoe Uyi Kizito and Udefuna, 
Patrick, 4(2013), 77-111.

54. Omollo, W. O., Hayombe, P. O., \& Owino, F. O. (2018). Spatio-Temporal Implications of Land-use Change in Kisii Town , Kenya, 7(2), 49-57. https://doi.org/10.23953/cloud.ijarsg.363

55. Overton, J. (1996). An introduction to sustainable development: The developing world. Journal of Rural Studies, 12(1), 89-90. https://doi.org/10.1016/S0743-0167(96)90049-2

56. Owoeye J, O. (2015). Urban development and land-use changes around the Ekiti State University ( EKSU ), AdoEkiti Nigeria, 8(4), 111-119. https://doi.org/10.5897/JGRP2015.0482

57. Pearce, A. R., \& Venegas, J. A. (2002). a Parametric Review of the Built Environment Sustainability. International Journal of Environmental Technology and Management, 2(1-3/2002), 54-93. https://doi.org/10.1504/IJETM.2002.000779

58. Pennington, M., \& Rydin, Y. (2000). Researching social capital in local environmental policy contexts. Policy \& Politics, Ogujiuba28(2), 233-249. https://doi.org/10.1332/0305573002500947

59. Peter, N. J., Fateye, O. B., Oloke, O., \& Praise, I. (2018). Changing urban landuse and neighborhood quality: Evidence from federal capital territory (FCT) Abuja, Nigeria. International Journal of Civil Engineering and Technology, 9(11), 23-36.

60. Polese, M., \& Stren, R. (2000). The social sustainabilityof cities: Diversity and the management of change.University of Toronto press. https://doi.org/10.3138/9781442682399

61. Putnam, R. D. (2000). Bowling alone: America's declining social capital. In In Culture and politics (pp. 223234). Palgrave Macmillan, New York. https://doi.org/10.1007/978-1-349-62397-6_12

62. Raheem, W., \& Adeboyejo, A. (2016). Urban greening and city sustainability in Ibadan metropolis, Nigeria. Ethiopian Journal of Environmental Studies and Management, 9(3), $287-302$. https://doi.org/10.4314/ejesm.v9i3.4

63. Rashidfarokhi, A., Yrjänä, L., Wallenius, M., Toivonen, S., Ekroos, A., \& Viitanen, K. (2018). Social sustainability tool for assessing land-use planning processes. European Planning Studies, 26(6), 1269-1296. https://doi.org/10.1080/09654313.2018.1461811

64. SDGs, N. (2015). Nigeria' s Road to SDGs Country Transition Strategy October 2015 Statement To rigorously integrate SDGs to ensure that goals inspire commitment, (October).

65. Simon, D. (2015). Our Common Future: Report of the World Commission on Environment and Development (Book Review). Third World Planning Review, 9(3), 285. https://doi.org/10.3828/twpr.9.3.x4k73r2p72w22402

66. Siong, H. C. (2007). Planning for Low Carbon Cities - The case of Iskandar Development Region , Malaysia. Middle East, 1-19.

67. Tomisi, A., Oluwatosin, F., \& Samson, \&Agbato. (2016). Determinants And Effects Of Change In Use On Property Rental Value A Case Study Ibara / Oke-Ilewo Area , Abeokuta , Ogun State, 21(4), 1-9. https://doi.org/10.9790/0837-2104040109

68. Tunmise, Ayodele T. and Abimbola, O. A. (2015). Implementation of Sustainable Development: the Impact of Social Sustainability. 2014 International Conference on Intelligent Agriculture, 63(16), $139-142$. https://doi.org/10.7763/ipcbee

69. UNDP. (2016). An Integrated Framework to Support Local Governance and Local Development.

70. Vardon, M., Burnett, P., \& Dovers, S. (2016). The accounting push and the policy pull: Balancing environment and economic decisions. Ecological Economics, 124, 145-152. https://doi.org/10.1016/j.ecolecon.2016.01.021

71. Verburg, P. H., Ritsema van Eck, J. R., de Nijs, T. C. M., Dijst, M. J., \& Schot, P. (2004). Determinants of landuse change patterns in the Netherlands. Environment and Planning B: Planning and Design, 31(1), $125-150$. https://doi.org/10.1068/b307

72. WCED. (1987). Our Common Future. Oxford Paperbacks. https://doi.org/10.2307/633499

73. Weingaertner, C., \& Moberg, A. (2011). Exploring socialsustainability: Learning from prespectives on urbandevelopment and companies and products. SustainableDevelopment. https://doi.org/10.1002/sd.536

74. WEO, W. E. R. (2009). Desertification- It's Effects on People and Land. World Ecology Report, 21(1), 1-6.

75. Xiao, L., Qiu, Q., \& Gao, L. (2016). Chinese housing reform and social sustainability: Evidence from post-reform home ownership. Sustainability (Switzerland), 8(10), 1-14. https://doi.org/10.3390/su8101053

76. Xie, H. (2017). Towards Sustainable Land-use in China: A Collection of Empirical Studies. Sustainability, 9(11), 2129. https://doi.org/10.3390/su9112129

77. Yung, E., \& Chan, E. H. W. (2016). Critical social sustainability factors in urban conservation : the case of the Central Police Station Compound in Hong Kong Article information :, (May).

78. Zheng, H. W., Shen, G. Q., Wang, H., \& Hong, J. (2015). Simulating land-use change in urban renewal areas: A case study in Hong Kong. Habitat International, 46, 23-34. https://doi.org/10.1016/j.habitatint.2014.10.008 